\title{
Host Barriers and Responses to Uncinula necator in Developing Grape Berries
}

\author{
Andrea Ficke, David M. Gadoury, Robert C. Seem, Dale Godfrey, and Ian B. Dry
}

First, second, and third authors: Department of Plant Pathology, Cornell University, New York State Agricultural Experiment Station, Geneva 14456; and fourth and fifth authors: Commonwealth Scientific Industry Research Organization (CSIRO) Plant Industry, Glen Osmond, SA 5064, Australia.

Current address of A. Ficke: Department of Plant Pathology, Wageningen University, P.O. Box 8025, Binnenhaven 5, Wageningen 6709, the Netherlands.

Accepted for publication 5 December 2003.

\section{ABSTRACT}

Ficke, A., Gadoury, D. M., Seem, R. C., Godfrey, D., and Dry, I. B. 2004. Host barriers and responses to Uncinula necator in developing grape berries. Phytopathology 94:438-445.

Grape berries are highly susceptible to powdery mildew 1 week after bloom but acquire ontogenic resistance 2 to 3 weeks later. We recently demonstrated that germinating conidia of the grape powdery mildew pathogen (Uncinula necator) cease development before penetration of the cuticle on older resistant berries. The mechanism that halts $U$. necator at that particular stage was not known. Several previous studies investigated potential host barriers or cell responses to powdery mildew in berries and leaves, but none included observation of the direct effect of these factors on pathogen development. We found that cuticle thickness increased with berry age, but that ingress by the pathogen halted before formation of a visible penetration pore. Cell wall thickness remained unchanged over the first 4 weeks after bloom, the time during which berries progressed from highly susceptible to nearly immune. Autofluorescent polyphenolic compounds accumulated at a higher frequency beneath appressoria on highly susceptible berries than on highly resistant berries; and oxidation of the above phenolics, indicated by cell discoloration, developed at a significantly higher frequency on susceptible berries. Beneath the first-formed appressoria of all germinated conidia, papillae occurred at a significantly higher frequency on 2- to 5-day-old berries than on 30- to 31-day-old fruit. The relatively few papillae observed on older berries were, in most cases ( 82.8 to $97.3 \%$ ), found beneath appressoria of conidia that had failed to produce secondary hyphae. This contrasted with the more abundantly produced papillae on younger berries, where only 35.4 to $41.0 \%$ were located beneath appressoria of conidia that had failed to produce secondary hyphae. A pathogenesis-related gene ( $V v$ PR-1) was much more highly induced in susceptible berries than in resistant berries after inoculation with $U$. necator. In contrast, a germin-like protein ( $V v$ GLP3) was expressed within $16 \mathrm{~h}$ of inoculation in resistant, but not in susceptible berries. Our results suggest that several putative barriers to infection, i.e., cuticle and cell wall thickness, antimicrobial phenolics, and two previously described pathogenesis-related proteins, are not principal causes in halting pathogen ingress on ontogenically resistant berries, but rather that infection is halted by one or more of the following: (i) a preformed physical or biochemical barrier near the cuticle surface, or (ii) the rapid synthesis of an antifungal compound in older berries during the first few hours of the infection process.

Additional keywords: adult plant resistance, grape diseases, Oidium, Vitis.
In earlier studies, we demonstrated that young berries of Vitis vinifera and $V$. labruscana are highly susceptible to Uncinula necator, but that they acquire ontogenic resistance within 2 to 4 weeks after bloom and are thereafter nearly immune to infection (8-10). We also described the quantitative effects of berry age upon germination, appressorium formation, development of secondary hyphae, colony expansion, latent period of the pathogen, and consequences of the foregoing for epidemic development and disease management programs (8-10). Our previous reports $(8-10)$, and those by many others $(1,3,6,21)$ have focused principally on the development of the pathogen, without addressing the host responses that might be taking place, and indeed be responsible for suppressing infection and subsequent pathogen growth in older resistant berries. In the present study, we considered both perspectives to correlate pathogen growth with responses in the host as grape berries acquire ontogenic resistance.

Heintz and Blaich (12) reported that cuticle thickness in leaves of various $V$. vinifera cultivars was positively correlated with their

Corresponding author: D. M. Gadoury; E-mail address: dmg4@ cornell.edu

Publication no. P-2004-0301-01R

(c) 2004 The American Phytopathological Society reported resistance to powdery mildew (12), but concomitant studies on the development of $U$. necator were not a part of this work. Also on grape leaves, Pratt et al. (16) observed papillae beneath appressoria of $U$. necator, and Heintz and Blaich (12) reported that papillae were associated with germinated conidia that failed to establish haustoria. Neither study provided conclusive evidence that either papillae stopped fungal ingress and subsequent haustorium formation in epidermal cells, or merely accompanied it. Chitinase $(7,17)$ and a thaumatin-like protein $(20)$ were suggested to be part of a defense response to powdery mildew infection in grape berries at veraison; the putative stage of fruit development at which fruit became resistant (6). However, ontogenic resistance is strongly expressed, and berries are nearly immune to infection by $U$. necator (8-10) several weeks before constitutive levels of the above compounds $(7,17,20)$ increased. Polyphenolics reportedly accumulate and oxidize at penetration sites in berry epidermal cells (12), but studies to demonstrate differential timing of synthesis with respect to berry age and ontogenic resistance, or involvement of polyphenolics in suppressing infection or subsequent pathogen growth, are lacking.

In the present study, we describe several anatomical and biochemical responses that occur in grape berries during infection by $U$. necator, how these host responses change with berry age, and whether or not such responses can be implicated as primary causes of ontogenic resistance. 


\section{MATERIALS AND METHODS}

Vines and vineyards. $V$. vinifera 'Chardonnay' vines planted in 5-liter plastic containers filled with Cornell soil mix (compressed peat and vermiculite mixed 1:2) were kept in cold storage $\left(4^{\circ} \mathrm{C}\right)$ for at least 4 months. Vines were removed from cold storage at staggered intervals and placed in a screen house, leading to the simultaneous development of different phenological stages, and allowing the evaluation of different-aged berries for effects of ontogenic resistance in a common environment. Ten days prior to inoculation, JMS Stylet Oil (1\%) (JMS Flower Farms Inc., Vero Beach, FL) was applied to foliage with a hand-held atomizer to eradicate any existing powdery mildew colonies.

Vineyard studies were conducted in single vine plots of Chardonnay and V. labruscana 'Concord' planted in 1974 and located in a 1-ha vineyard at the New York State Agricultural Experiment Station (NYSAES) at Geneva, New York. Chardonnay vines bloomed (50\% cap-fall) on 17 June 1999 and 22 June 2001. Concord vines bloomed on 21 June 1996. The vines were canepruned and Umbrella-Kniffen trained. Additional vineyard studies were conducted in single-cluster plots of Chardonnay in 1999, 2000, and 2001, and on Riesling in 2001 at the Commonwealth Scientific Industry Research Organization (CSIRO) in Adelaide, South Australia. Vines were pruned to 22 nodes per meter row, single-wire trained with no foliage positioning. Chardonnay vines bloomed (50\% cap fall) on 20 October 1999, 1 November 2000, and 12 November 2001. Riesling vines bloomed on 6 November 2001.

Vines at NYSAES and CSIRO were sprayed each year with a variety of fungicides at 10- to 12-day intervals, beginning at 7 to $15 \mathrm{~cm}$ shoot length to control powdery mildew. To provide fruit for inoculation that were both disease-free and free of fungicide residues, clusters in all vineyards scheduled for inoculation within the residual time of the applied fungicide were bagged with clear polyethylene bags during the spray application immediately prior to inoculation, and during all sprays applied subsequent to the inoculation as described by Gadoury et al. (9). Bags were removed from the clusters as soon as the spray was dry (approximately $1 \mathrm{~h}$ postspray).

Cuticle and cell wall thickness. Changes in cuticle and cell wall thickness were recorded for Concord and Chardonnay berries in 1996 and 1999, respectively, at NYSAES. Two to three berries from each of three Chardonnay clusters were collected at 10, 21, and 28 days after bloom. Hand sections were prepared by cutting each berry in half and preparing a 1- to 2-mm-thick and 3- to 5 -mm-deep wedge from the berry face. These sections were fixed in formalin-acetic acid-alcohol, dehydrated in tertiary butyl alcohol, and embedded in paraffin (13). Paraffin sections (10 to $12 \mu \mathrm{m}$ thick) were cut on a rotary microtome (American Optical, Buffalo, NY), mounted on glass slides with Haupt's adhesive (13), dewaxed in Histoclear (National Diagnostics, Somerville, NJ), and rehydrated in an ethanol series (13). Sections were then stained in $0.05 \%$ trypan blue in lactophenol for $5 \mathrm{~min}$ (15), dehydrated in ethanol, and mounted in Permount (Fisher Scientific, Fair Lawn, NJ). The thickness of the cuticle and outer cell wall of five epidermal cells per section from each of two sections per berry was measured at $\times 400$ magnification with an ocular micrometer. Samples of Concord berries were collected at NYSAES at 3,8 , and 15 days after bloom in 1996, and were similarly processed and sectioned. Cuticle and epidermal cell wall thickness were measured as described for Chardonnay sections.

Accumulation of phenolic compounds during infection. At NYSAES, two cohorts, each consisting of a single potted Chardonnay vine, were removed from cold storage 2 weeks apart and grown in the greenhouse to bear fruit either 7 or 21 days old on the same day. Ten berries from each of two clusters per vine were individually inoculated by touching leaf disks covered with newly sporulating colonies of powdery mildew to the berries. Two to three berries per cluster were collected 4, 8, 14, and $28 \mathrm{~h}$ after inoculation. Disks of epidermal tissue were cut from the berries as described by Ficke et al. (8) and mounted in water on glass slides. Tissue was observed with a fluorescence microscope at $\times 400$ (near-UV light, excitation filter 360 to $370 \mathrm{~nm}$, dichroic mirror $400 \mathrm{~nm}$, emitter $420 \mathrm{~nm}$ ). A blue autofluorescence surrounding appressoria of $U$. necator indicated the localized accumulation of phenolic compounds. From 30 to 50 conidia per berry were examined, and at each time interval the presence or absence of autofluorescence surrounding appressoria was recorded.

The experiment was expanded and repeated at CSIRO under field conditions, where 25 Chardonnay clusters were inoculated with an atomized aqueous suspension of $U$. necator containing $10^{5}$ conidia $\mathrm{ml}^{-1}$ as described by Gadoury et al. (9) at either 7 or 24 days after bloom. Five berries per cluster from each of five clusters per treatment were collected 2 days after inoculation. Disks of epidermal tissue were mounted on glass slides in water and viewed under fluorescence microscopy at $\times 400$. Autofluorescence, germination, appressorium formation, and formation of secondary hyphae was assessed as described previously.

Cell discoloration following phenolic accumulation. In 1999, 35 Chardonnay clusters were inoculated with an atomized aqueous suspension of $U$. necator containing $10^{5}$ conidia $\mathrm{ml}^{-1}$ as described by Gadoury et al. (9) at the CSIRO vineyard 14 and 28 days after bloom. Five berries per cluster from each of five clusters were collected 9 days after inoculation. Disks of epidermal tissue were prepared as described again and viewed under brightfield microscopy at $\times 400$. For each appressorium along the longest hyphal strand observed on each disk, the position of the appressorium along the hyphae relative to the conidium, and the diameter of any area beneath an appressorium displaying the amber-brown discoloration characteristic of oxidized phenolics was recorded. The experiment was repeated in 2000 and 2001 at the CSIRO vineyard. In 2000, Chardonnay clusters were inoculated 7 days after bloom. Five berries were collected from each of five clusters 7 days after inoculation, and were examined as described previously. In 2001, 10 Riesling and 15 Chardonnay clusters were inoculated at 2 or 4 days after bloom, respectively, and 30 or 31 days after bloom, respectively. Disks of epidermal tissue were cut from the berries after $24 \mathrm{~h}$ as previously described (8), fixed, cleared in methyl salicylate (8), and examined microscopically. Total number of appressoria and number of appressoria associated with this cell discoloration on susceptible and resistant berries was recorded.

The experiment was repeated at NYSAES and CSIRO in 2001 using detached berries. At NYSAES, 10 berries were collected in the vineyard from each of three Chardonnay clusters at either 5 or 31 days after bloom and placed in microtiter plates ( 24 wells per plate, Becton Dickinson Labware, Becton Dickinson and Company, Franklin Lakes, NJ) filled with $1 \%$ water agar. Berries were then inoculated using a previously described (8) spore-settling tower, and were incubated in a growth chamber at $22^{\circ} \mathrm{C}, 75 \% \mathrm{RH}$ for $24 \mathrm{~h}$. Disks cut as described previously from each berry were fixed in warm lactophenol and cleared in methyl salicylate as described by Ficke et al. (8) and viewed under differential interference microscopy. At CSIRO, the experiment was modified as follows: 20 Riesling or 25 Chardonnay berries per each of three to five clusters were picked in the vineyard at their susceptible ( 2 to 4 days after bloom) and resistant stage (30 to 31 days after bloom). Berries were incubated in a growth chamber at $21^{\circ} \mathrm{C}$, $75 \%$ RH.

Papillum formation and associated responses. In 2001 at NYSAES, 10 berries were picked from each of three Chardonnay clusters at either 5 or 31 days after bloom and placed in microtiter plates filled with $1 \%$ water agar. The berries were inoculated in the spore-settling tower and then incubated in the growth chamber at $22^{\circ} \mathrm{C}, 75 \% \mathrm{RH}$. At 24 and $72 \mathrm{~h}$ postinoculation, disks of epidermal tissue from each of three berries per cluster were fixed in lactophenol, cleared and mounted in methyl salicylate as de- 
scribed by Ficke et al. (8), and viewed at $\times 1,000$ under differential interference microscopy. Papillum formation and diameter at the site of appressoria, as well as cell discoloration and development of secondary hyphae, was recorded on each berry disk. In the same experiment, disks were cut from five berries from each of three Chardonnay clusters at $72 \mathrm{~h}$ postinoculation, fixed in $70 \%$ ethanol overnight, hydrated in an ethanol series, and stained overnight in a $0.03 \%$ (wt/vol) aqueous solution of the fluorochrome aniline blue, which differentially stains the callose accumulations of papillae (Sirofluor, Biosupplies Australia, Park- ville, Australia). Disks were mounted in distilled water on glass slides and viewed with a fluorescence microscope at $\times 400$. Papillae in epidermal cells fluoresced yellow-green.

The above study was repeated in 2001 at CSIRO, where 10 Riesling and 12 Chardonnay clusters were inoculated in the vineyard with an aqueous spore suspension by an atomizer at 2 or 4 days after bloom, respectively, and 30 or 31 days after bloom, respectively. At 24 and $72 \mathrm{~h}$ postinoculation, disks of epidermal tissue from three to five berries of each of three to five clusters were prepared and examined as described previously.
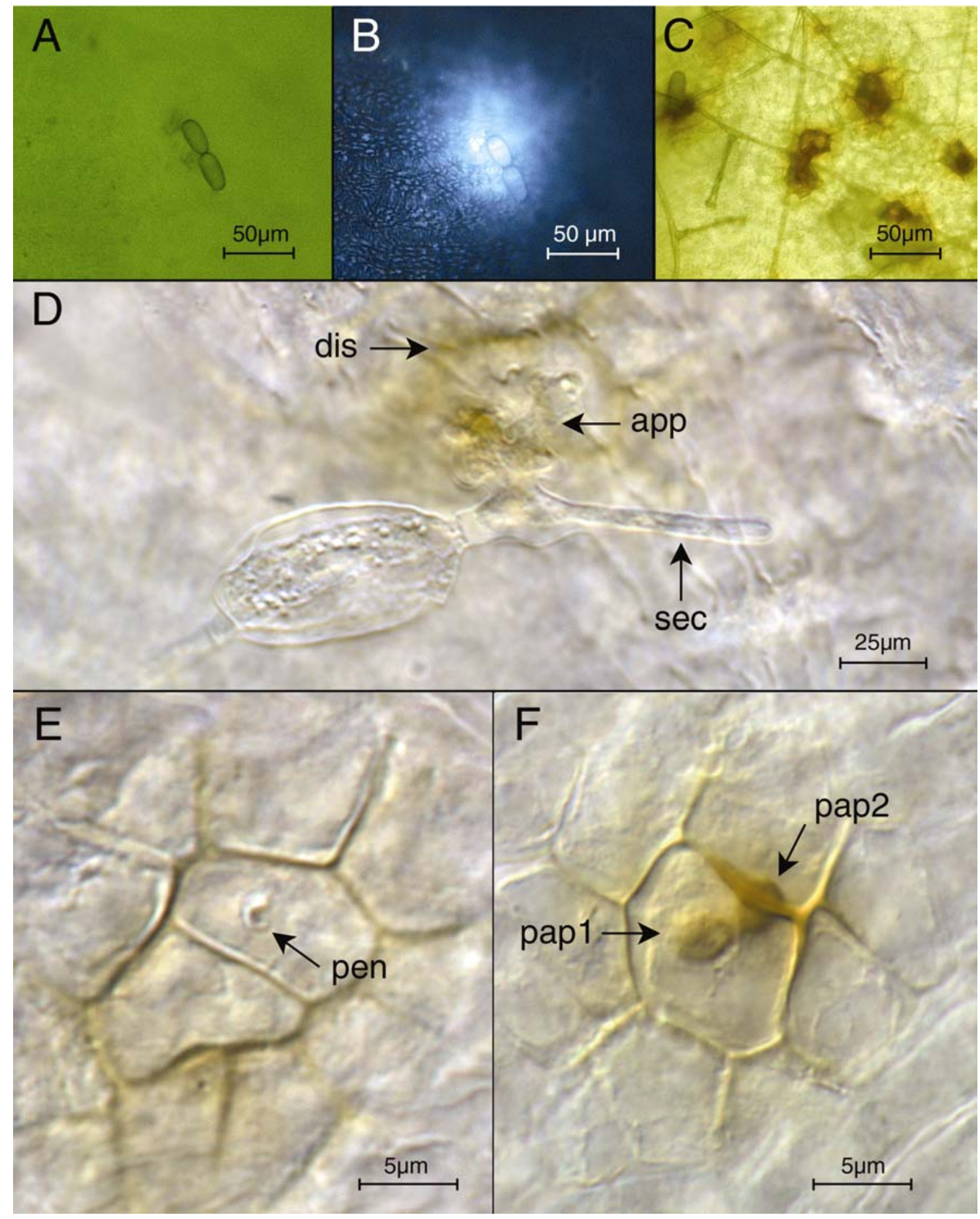

Fig. 1. A, Brightfield micrograph of germinated conidia of Uncinula necator $12 \mathrm{~h}$ after inoculation of a 7-day-old 'Chardonnay' berry. B, Near-UV illumination of the same conidia showing autofluorescence of polyphenolics in nearby epidermal cells. C, Discoloration of epidermal cells beneath appressoria 7 days after inoculation of 7-day-old Chardonnay berry. Differential interference micrographs of D, germinated conidium of U. necator on 7-day-old Chardonnay berry showing lobate appressorium (app), secondary hypha (sec), and incipient discoloration (dis) of epidermal cells at $24 \mathrm{~h}$ postinoculation; E, penetration pore (pen) beneath appressorium on 7-day-old Chardonnay berry at $24 \mathrm{~h}$ postinoculation; and F, papillae formed beneath penetration pore (pap1) and at anticlinal wall (pap2) of 7-day-old Chardonnay berry at $24 \mathrm{~h}$ postinoculation. 
In addition, the study was repeated at CSIRO using detached berries. Twelve berries from each of three Riesling clusters and 15 berries from each of five Chardonnay clusters were picked at 2 or 4 days after bloom, respectively, and at 30 or 31 days after bloom, respectively. Berries were placed in microtiter plates filled with $1 \%$ water agar, inoculated in the spore-settling tower, and incubated at $22^{\circ} \mathrm{C}, 75 \% \mathrm{RH}$ for 24 or $72 \mathrm{~h}$. Disks of epidermal tissue were then prepared and examined as described previously.

Gene expression. Differential expression of selected genes following inoculation of different-aged berries was investigated at CSIRO in 1999 and 2001. From 30 to 40 grape clusters were inoculated with an aqueous suspension of conidia as previously described (9) at either a susceptible age ( 7 to 14 days after bloom) or at a resistant age (33 to 39 days after bloom). In 1999, two to three susceptible berries were picked from each cluster immediately before inoculation, and 2, 4, 8, 12, 16, 20, 24, and $48 \mathrm{~h}$, and 8 and 19 days after inoculation, frozen in liquid nitrogen, and stored at $-80^{\circ} \mathrm{C}$. Resistant berries were sampled at the same time intervals within the first $48 \mathrm{~h}$ after inoculation, but not thereafter. In 2001, 90 to 100 susceptible or resistant berries were picked immediately before inoculation, and $12,16,20,24$, and $48 \mathrm{~h}$ after inoculation, frozen in liquid nitrogen, and stored at $-80^{\circ} \mathrm{C}$. Watersprayed clusters served as controls in the above experiments.

The experiment was repeated at CSIRO in 2001 using detached Chardonnay clusters with the following modifications. Twentyfive mildew- and fungicide-free clusters were collected and surface-sterilized for $3 \mathrm{~min}$ in a Milton-water solution $(1: 1, \mathrm{vol} / \mathrm{vol})$ (8). Fifteen clusters were inoculated in the spore-settling tower, and 10 noninoculated clusters served as controls. The clusters were incubated in airtight containers at $25^{\circ} \mathrm{C}$. Immediately before inoculation, and at $12,16,20$, and $48 \mathrm{~h}$ after inoculation, five to six berries were removed from each inoculated and noninoculated cluster, frozen in liquid nitrogen, and stored at $-80^{\circ} \mathrm{C}$.

The frozen skins were freed from the pulp, and the berry skins were ground while frozen to yield a fine powder. Total RNA from berry skin tissue ( 1 to $2 \mathrm{~g}$ ) was extracted by the perchlorate extraction method (5) and stored at $-80^{\circ} \mathrm{C}$. Concentration and purity of RNA was determined photometrically (18).

Semiquantitative analysis of gene expression in berry samples was carried out with the SuperScript One-Step reverse transcriptase-polymerase chain reaction (RT-PCR) with Platinum Taq kit (Invitrogen, Carlsbad, CA). Semiquantitative analysis is achieved by comparing product yield at a fixed PCR cycle number within the exponential phase of the PCR followed by detection of products by Southern blot analysis. This technique is more sensitive and requires less RNA than traditional northern blot techniques. The reaction was carried out essentially as described in the manufacturer's instructions with the modification that an oligo(dT)adapter primer (5'-GACTCGAGTCGACATCGATTTTTTTTTTTTTTTTT-3') was used in place of a $3^{\prime}$-gene-specific primer to direct first-strand cDNA synthesis from the poly-A tail of mRNA transcripts. Each $20 \mu \mathrm{l}$ of RT-PCR reaction contained $10 \mu \mathrm{l}$ of $2 \times$ reaction mix, $2 \mu \mathrm{l}$ of berry skin total RNA $\left(40 \mathrm{ng}^{-1} \mathrm{l}^{-1}\right), 0.4 \mu \mathrm{l}$ of 5 '-gene-specific primer $(10 \mu \mathrm{M}), 0.4 \mu \mathrm{l}$ of oligo(dT)-adapter primer B26 $(10 \mu \mathrm{M}), 0.4 \mu \mathrm{l}$ of RT/Taq enzyme mix, and $6.8 \mu \mathrm{l}$ of RNasefree water. Gene-specific primer sequences were designed to $V$. vinifera cDNA sequences for $\beta$-tubulin (GenBank Accession No. CB968647), a germin-like protein ([GLP] VvGLP3; GenBank Accession No. AY298727), and a pathogenesis-related type 1 protein ( $V v$ PR-1; GenBank Accession No. AY298726). The primer sequences were $\beta$-tubulin (5'-GCCCAGAAGAGAATTATGAGGCC-3'), $V v$ GLP3 (5'-TGACCCCAAGGATGGTGTGTTC), and $V v$ PR-1 (5'-GAGGGTGGTTCGTCACATGC-3'). V. vinifera $\beta$ tubulin is constitutively expressed in all tissues and was therefore used to check for equal RNA concentration in each RT-PCR reaction. Reaction conditions for RT-PCR amplification were as follows: $50^{\circ} \mathrm{C}$ for $30 \mathrm{~min}, 94^{\circ} \mathrm{C}$ for $2 \mathrm{~min}$ followed by 25 ( $\beta$-tubulin) to $30(V v \mathrm{PR}-1, V v \mathrm{GLP} 3)$ cycles of $94^{\circ} \mathrm{C}$ for $15 \mathrm{~s}, 55^{\circ} \mathrm{C}$ for $30 \mathrm{~s}$ and $72^{\circ} \mathrm{C}$ for $1 \mathrm{~min}$, and followed by a final extension step of $72^{\circ} \mathrm{C}$ for $10 \mathrm{~min}$. The products of the RT-PCR reactions were loaded onto a $1.2 \%$ Tris-borate-EDTA agarose gel and electrophoresed for 1 to $2 \mathrm{~h}$ at 90 to $100 \mathrm{~V}$. DNA was transferred to Zeta-Probe membrane (GT-Bio-Rad, Richmond, CA) using $0.4 \mathrm{M} \mathrm{NaOH}$. Blots were probed with ${ }^{32} \mathrm{P}$-labeled DNA probes of $\beta$-tubulin, $V v \mathrm{PR}-1$, and $V v \mathrm{GLP} 3$, which were PCR generated using genespecific primers (described previously), gel purified, and labeled using a Gigaprime labeling kit (GeneWorks, Adelaide, Australia). The relative levels of amplified RT-PCR product in each track was visualized by exposing them to X-ray film for 0.5 to $2 \mathrm{~h}$.

Statistical analysis. Comparison of two-treatment effects was based on Student's $t$ test. Regression analyses were generated using the REGRESS operation of Minitab 10.51 (Minitab Inc., State College, PA).

\section{RESULTS}

Cuticular and cell wall thickness. The thickness of the cuticle of Concord berries increased from $3.5 \mu \mathrm{m}(\mathrm{SE}=0.25 \mu \mathrm{m})$ to $4.6 \mu \mathrm{m}(\mathrm{SE}=0.34 \mu \mathrm{m})$ to $9.63 \mu \mathrm{m}(\mathrm{SE}=0.41 \mu \mathrm{m})$ at 3,8 , and 15 days postbloom, respectively. The cuticle of Chardonnay berries increased in thickness from $2.3 \mu \mathrm{m}(\mathrm{SE}=0.16 \mu \mathrm{m})$ to $2.5 \mu \mathrm{m}$ $(\mathrm{SE}=0.24 \mu \mathrm{m})$ to $3.2 \mu \mathrm{m}(\mathrm{SE}=0.11 \mu \mathrm{m})$ at 10,21 , and 28 days postbloom, respectively. Within cultivar, differences observed between the youngest and oldest stage were significant at $P=0.05$.

Thickness of the periclinal walls of epidermal cells did not increase significantly $(P=0.10)$ during development of either Concord or Chardonnay berries. Wall thickness was $2.50 \mu \mathrm{m}(\mathrm{SE}=$ $0.00 \mu \mathrm{m}), 2.63 \mu \mathrm{m}(\mathrm{SE}=0.08 \mu \mathrm{m})$, and $2.50 \mu \mathrm{m}(\mathrm{SE}=0.00 \mu \mathrm{m})$ at 3,8 , and 15 days after bloom of Concord. Comparable values for Chardonnay berries were $1.06 \mu \mathrm{m}(\mathrm{SE}=0.045 \mu \mathrm{m}), 1.08 \mu \mathrm{m}$ $(\mathrm{SE}=0.087 \mu \mathrm{m})$, and $1.02 \mu \mathrm{m}(\mathrm{SE}=0.022 \mu \mathrm{m})$ at 10,21 , and 28 days postbloom, respectively.

Accumulation of phenolic compounds during infection. In all experiments, autofluorescence was more frequently associated with infection of younger, more susceptible rather than older, more resistant berries. On 7-day-old Chardonnay berries collected from potted grapevines at NYSAES, appressoria, but no autofluorescence, were observed at 4 and $8 \mathrm{~h}$ after inoculation. At $14 \mathrm{~h}$, an intense autofluorescence (Fig. 1A and B) typical of accumulated phenolic compounds was observed beneath $53.4 \%$ $(\mathrm{SE}=5.87 \%)$ of the appressoria on 7-day-old berries. However, autofluorescence was observed beneath only $4.7 \%(\mathrm{SE}=2.79 \%)$ of the appressoria on 24-day-old berries. The frequency of autofluorescence did not increase significantly between 14 and $28 \mathrm{~h}$ on either 7 - or 24 -day-old berries $(P=0.05)$, although on the 7 -day-old berries the autofluorescent area did expand between 14 and $28 \mathrm{~h}$ to include epidermal cells surrounding the appressorium in addition to those beneath the appressorium.

A similar relationship between berry age at inoculation and autofluorescence of berry epidermal cells beneath and appressoria was observed when the study was repeated at CSIRO (Table 1).

TABLE 1. The percentage of conidia of Uncinula necator with and without secondary hyphae associated with autofluorescence on Vitis vinifera 'Chardonnay' berries inoculated 7 or 24 days after bloom

\begin{tabular}{|c|c|c|c|c|c|c|c|c|}
\hline \multirow[b]{3}{*}{ Age } & \multicolumn{4}{|c|}{$\begin{array}{c}\text { Conidia with } \\
\text { secondary hyphae }\end{array}$} & \multicolumn{4}{|c|}{$\begin{array}{c}\text { Conidia without } \\
\text { secondary hyphae }\end{array}$} \\
\hline & \multicolumn{2}{|c|}{$\begin{array}{l}\text { Auto- } \\
\text { fluorescence }\end{array}$} & \multicolumn{2}{|c|}{$\begin{array}{l}\text { No auto- } \\
\text { fluorescence }\end{array}$} & \multicolumn{2}{|c|}{$\begin{array}{l}\text { Auto- } \\
\text { fluorescence }\end{array}$} & \multicolumn{2}{|c|}{$\begin{array}{l}\text { No auto- } \\
\text { fluorescence }\end{array}$} \\
\hline & Mean & SE & Mean & SE & Mean & SE & Mean & $\mathrm{SE}$ \\
\hline 7 & 33.21 & 12.06 & 29.05 & 13.01 & 28.79 & 10.68 & 8.95 & 4.31 \\
\hline 24 & 1.98 & 1.24 & 27.49 & 13.83 & 0.00 & 0.00 & 70.53 & 12.62 \\
\hline
\end{tabular}

$\mathrm{z}$ Percentage of primary appressoria beneath which autofluorescence was or was not observed at $48 \mathrm{~h}$ after inoculation. $\mathrm{SE}=$ standard error of the mean. Age refers to berry age (days after bloom) at time of inoculation. 
Additionally, on 7-day-old berries inoculated in the vineyard, success or failure in producing secondary hyphae (Fig. 1D) after infection was not related to autofluorescence; i.e., an equivalent $(P=0.05)$ percentage of conidia that had formed secondary hyphae induced $(33.21 \%)$ or did not induce $(29.05 \%)$ autofluorescence (Table 1). In contrast, on 24-day-old berries, all conidia that failed to form secondary hyphae $(70.53 \%)$ also failed to induced autofluorescence (Table 1). Among conidia that produced secondary hyphae on 24-day-old berries, only $1.98 \%$ induced autofluorescence compared with $27.49 \%$ that did not induce autofluorescence (Table 1).

Cell discoloration following phenolic accumulation. Among inoculated Chardonnay berries of all ages, epidermal cells beneath some (but not all) appressoria of $U$. necator exhibited a light brown discoloration (Fig. 1C) beginning 18 to $24 \mathrm{~h}$ after inoculation. Discoloration of cells beneath appressoria occurred at a higher frequency on younger than on older berries, and

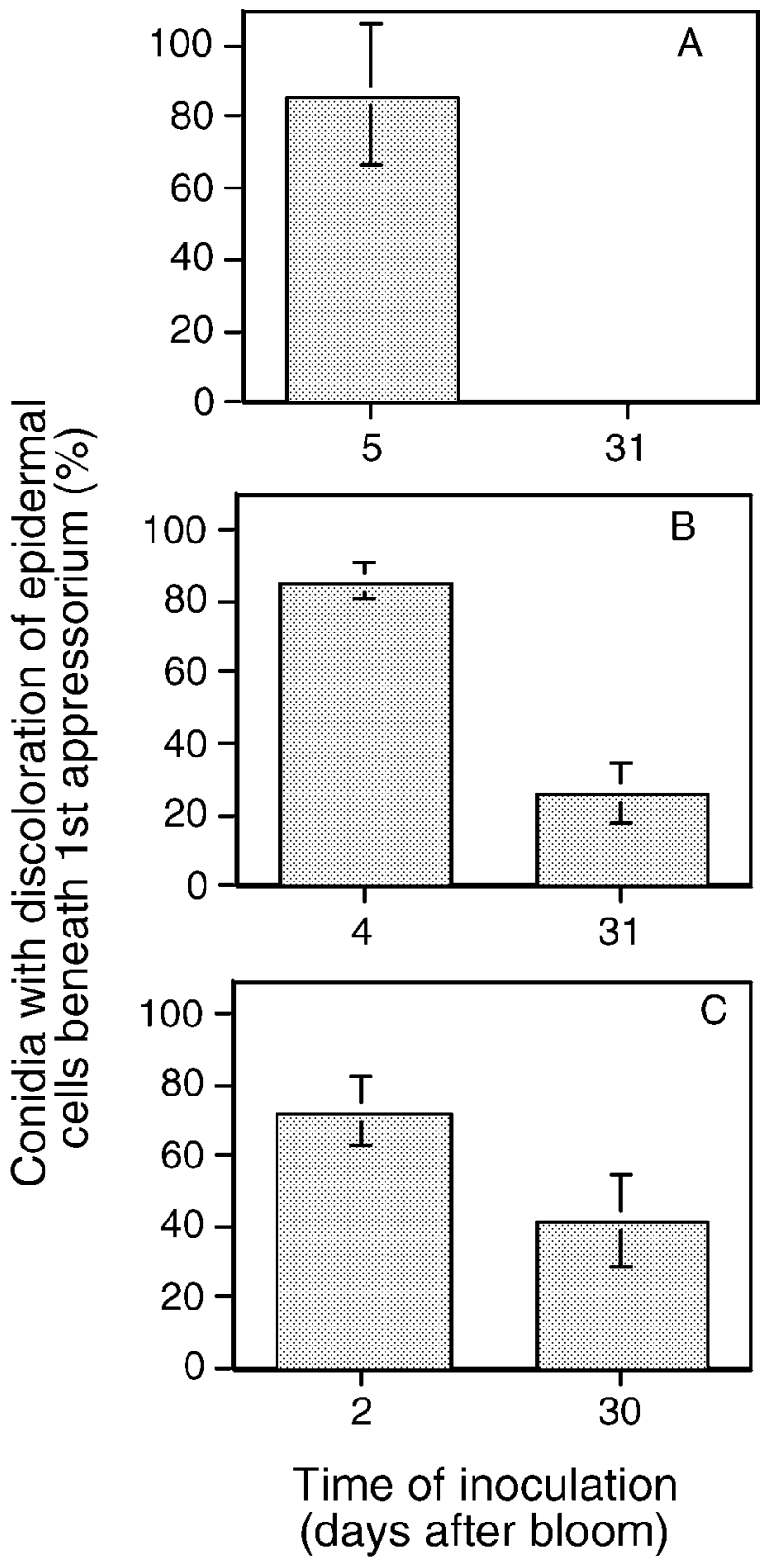

Fig. 2. Frequency of discoloration of epidermal cells beneath proximal appressoria of Uncinula necator on berries of Vitis vinifera $\mathbf{A}$ and $\mathbf{B}$, 'Chardonnay' and $\mathbf{C}$, 'Riesling' inoculated at different stages of berry development. Error bars indicate one standard error of the mean. initially appeared more intense in those cells adjacent to the penetrated cell (Fig. 1D and E). On Chardonnay berries inoculated 5 days after bloom at NYSAES in 2001, significantly more $(P=$ $0.01)$ conidia were associated with discoloration of the epidermal cells beneath the first-formed appressorium than on berries inoculated 31 days after bloom (Fig. 2A). Similar significant $(P=0.05)$ differences were observed at CSIRO in 2001 when Chardonnay berries were inoculated 4 days versus 31 days after bloom (Fig. 2B) and sampled $24 \mathrm{~h}$ later, and when Riesling berries were inoculated 2 days versus 30 days after bloom $(P=0.09)$ and sampled $24 \mathrm{~h}$ later (Fig. 2C).

The diameter and intensity of the discolored area increased with position of appressoria along the hyphae, i.e., with the age of an appressorium or duration of its association with the host. Regression of appressorial position against diameter of the discolored area 9 days postinoculation yielded the following equations for berries 14 (Fig. 3A) or 28 (Fig. 3B) days old, respectively, at the time of inoculation: $Y=15.409-10.256\left(\log _{10}\right) X ; R^{2}=0.93$ (14-day-old berries), or $Y=12.891-9.674\left(\log _{10}\right) X ; R^{2}=0.66$ (28-day-old berries); where $Y$ is the diameter of the discolored area measured in micrometers, and $X$ is the position of the appressorium relative to the germinated conidium; appressorial position 1 being the first produced and therefore oldest (Fig. 2). The $y$ intercepts of the above equations were significantly different at $P=$ 0.05 , but their slopes were similar, indicating an initially higher level of discoloration in younger berries, but a similar trend in development of discoloration related to duration of association with appressoria (Fig. 3).

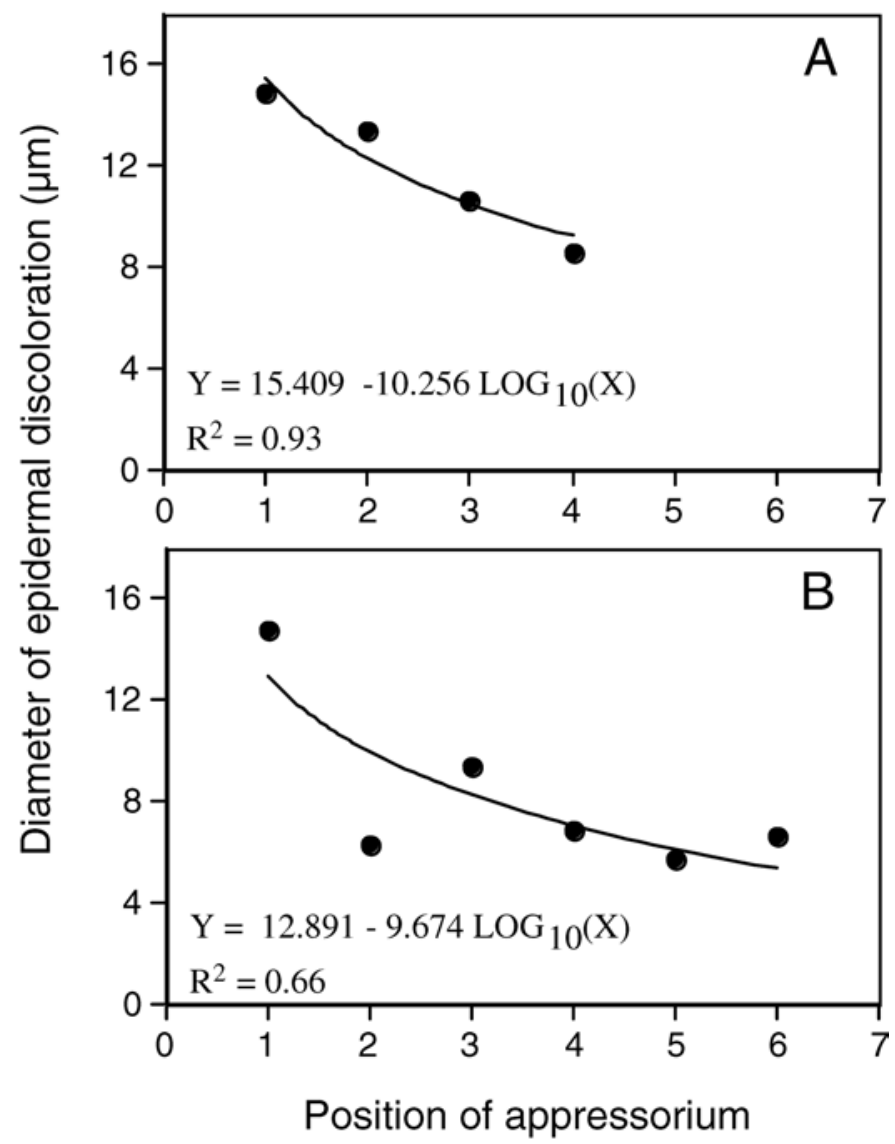

Fig. 3. Diameter of discoloration of epidermal cells beneath appressoria of different ages during growth of Uncinula necator on grape berries of Vitis vinifera 'Chardonnay' inoculated at A, 14 or B, 28 days after bloom. Discoloration was assessed 9 days after inoculation. The position of an appressorium on a hypha relative to a germinated conidium was recorded; appressorial position 1 being the first produced by the conidium and therefore the oldest. 
A similar relationship between age of appressoria and discoloration of epidermal cells beneath appressoria was observed when the study was repeated (Fig. 4). Regression of appressorial position against diameter of the discolored area yielded the following equation: $Y=14.02-1.13 X$; where $Y$ is the diameter of the discolored area measured in micrometers, and $X$ is the position of the appressorium relative to the germinated conidium $\left(R^{2}=0.78\right)$.

Papillum formation. Papillae averaged $2.0 \mu \mathrm{m}$ in diameter in both younger and older Chardonnay berries $24 \mathrm{~h}$ after inoculation (Fig. 1F). Among all conidia that germinated and formed appressoria, papillae generally subtended appressoria on young susceptible berries (inoculated 2 to 5 days after bloom) at a higher frequency than on older resistant berries (inoculated 30 to 31 days after bloom). In reference to the younger berries, the increased frequency of the presence of a papillum beneath the first-formed appressorium was significant $(P=0.05) 24 \mathrm{~h}$ after inoculation of both Chardonnay and Riesling berries (Fig. 5A, B, and F), by $72 \mathrm{~h}$ after inoculation of Riesling berries (Fig. 5D), but not at $72 \mathrm{~h}$ after inoculation of Chardonnay berries (Fig. 5C and E). The relatively few papillae observed on older berries were, in most cases ( 82.8 to $97.3 \%$ ), found beneath appressoria of conidia that had failed to produce secondary hyphae. This contrasted with the more abundantly produced papillae on younger berries, where only 35.4 to $41.0 \%$ were located beneath appressoria of conidia that had failed to produce secondary hyphae (Table 2).

Gene expression. Initially, we undertook northern blot analysis of defense gene expression in skins of sensitive and resistant Chardonnay berries immediately after inoculation with powdery mildew. This technique was unsuccessful because it was not sensitive enough to detect changes in gene expression within the first $48 \mathrm{~h}$ after infection. To improve the sensitivity of the expression analysis, we employed a semiquantitative RT-PCR/Southern blot analysis technique. Expression of the $\beta$-tubulin gene was chosen as a control because of its ubiquitous expression in berry skins throughout Chardonnay berry development. Figure 6 shows the expression profile obtained for $\beta$-tubulin after 25 cycles of amplification across all berry skin samples. Although there was some variation in product levels observed, these apparent differences in total RNA concentration could not account for the observed differences in defense gene induction between inoculated and uninoculated samples described below.

Using RT-PCR conditions optimized for $\beta$-tubulin, expression of various pathogenesis-related (PR) genes was analyzed. Of the

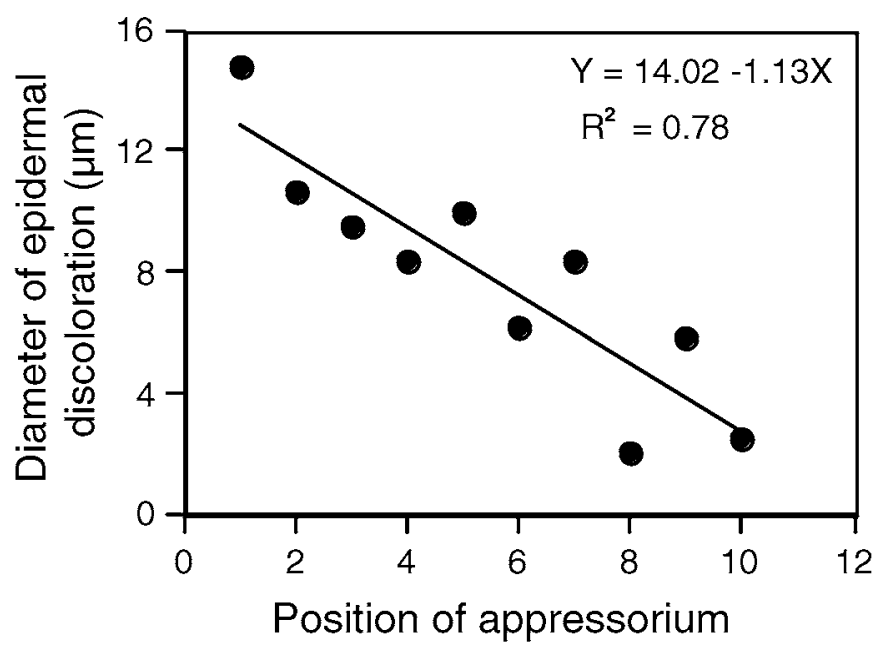

Fig. 4. Diameter of discoloration in epidermal cells beneath appressoria of different ages produced during growth of Uncinula necator on grape berries of Vitis vinifera 'Chardonnay'. Berries were inoculated 7 days after bloom, and discoloration was assessed 7 days later. The position of an appressorium on a hypha relative to a germinated conidium was recorded; appressorial position 1 being the first produced by the conidium and therefore the oldest.
PR genes tested, $V v$ PR-1 was found to be most suitable because it showed negligible expression in uninoculated berry skins as shown in Figure 6. PR-1 expression increased significantly $48 \mathrm{~h}$ postinoculation. However, older berries showed a much lower level of PR-1 expression at this stage than younger ones.

We have recently isolated and characterized the GLP gene family in grapevine (D. Godfrey and B. Dry, unpublished data). The protein encoded by one member of this gene family, $V v$ GLP3, is thought to be located within the extracellular space of grape epidermal cells, and is specifically induced during powdery
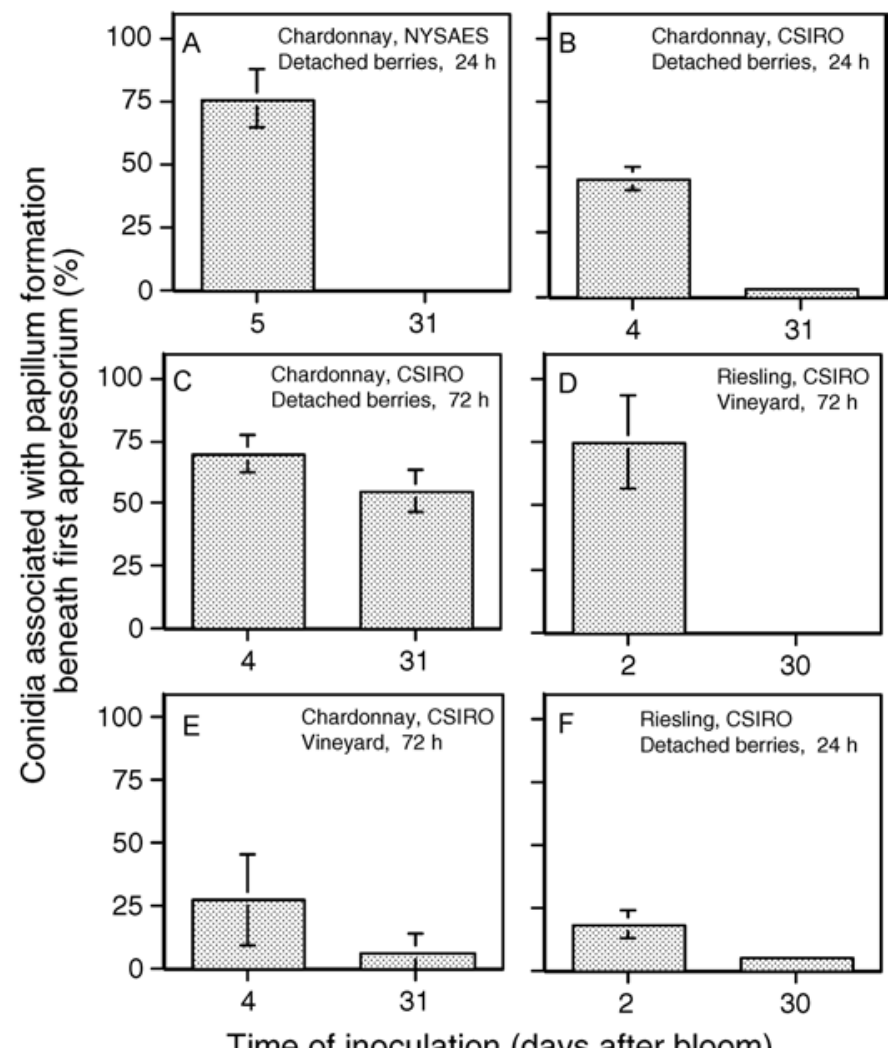

Time of inoculation (days after bloom)

Fig. 5. Papillum formation beneath the first-formed appressorium of conidia of Uncinula necator on young susceptible and older resistant 'Chardonnay' and 'Riesling' berries at A, New York State Agricultural Experiment Station (NYSAES), Geneva, and B to F, Commonwealth Scientific Industry Research Organization (CSIRO), Adelaide, Australia. Berries were either $\mathbf{A}$ to $\mathbf{C}$ and $\mathbf{F}$, detached from vines, inoculated, and incubated under controlled conditions in the laboratory or $\mathbf{D}$ and $\mathbf{E}$, inoculated and left attached to vines. Presence of papillae beneath the first-formed appressorium of germinated conidia was assessed microscopically at $\mathbf{A}, \mathbf{B}$, and $\mathbf{F}, 24 \mathrm{~h}$ or $\mathbf{C}$ to $\mathbf{E}, 72 \mathrm{~h}$ after inoculation.

TABLE 2. Frequency of association of papillae observed in epidermal cells with the appressoria of conidia failing to form secondary hyphae on Vitis vinifera 'Chardonnay' berries of various ages at New York State Agricultural Experiment Station (NYSAES), Geneva, and Commonwealth Scientific Industry Research Organization (CSIRO), Adelaide, Australia

\begin{tabular}{lccc}
\hline Location & $\begin{array}{c}\text { Time of inoculation } \\
\text { (days after bloom) }\end{array}$ & $\begin{array}{c}\text { Percentage of papillae situated } \\
\text { beneath appressoria of conidia that } \\
\text { failed to form secondary hyphae }\end{array}$ & $\begin{array}{c}\text { SE } \\
(\%)\end{array}$ \\
\hline NYSAES & 5 & 35.4 & 9.59 \\
& 31 & 97.3 & 2.72 \\
CSIRO & 4 & 41.0 & 3.36 \\
& 31 & 82.8 & 3.04 \\
\hline
\end{tabular}

${ }^{\mathrm{z}}$ Percentage of papillae (of total observed) that were located beneath appressoria of conidia that failed to form secondary hyphae on berries of indicated ages. Detached Chardonnay berries were inoculated with conidia, incubated for $24 \mathrm{~h}$ (NYSAES) or $72 \mathrm{~h}$ (CSIRO), and examined microscopically. SE = standard error. 
mildew infection. We therefore investigated the induction of this gene in susceptible and ontogenically resistant berries. Chardonnay berries inoculated 7 days after bloom did not show expression above background levels of VvGLP3 at $0,12,16,20$, and $48 \mathrm{~h}$ after inoculation (Fig. 6). However, berries inoculated 39 days after bloom showed increasing induction of $V v$ GLP3 expression from 16 to $48 \mathrm{~h}$ after inoculation (Fig. 6). Noninoculated control berries, sampled along side berries inoculated 39 days after bloom, showed no significant expression of this gene above background levels (Fig. 6).

\section{DISCUSSION}

In a previous paper (8), we reported aspects of our investigations pertaining to the effects of ontogenic resistance on the establishment and growth of $U$. necator on grape berries. Ontogenic resistance reduced the proportion of propagules that became established, inhibited the growth of those propagules that did establish, and through its effects upon latent period and sporophore density, it reduced the potential for secondary cycles of grape powdery mildew (8). While conidial attachment, germination, and appressorium formation were not affected by berry age, successful penetration of berries, formation of haustoria, and development of secondary hyphae often declined to either nil or trace levels once ontogenic resistance was fully expressed in older berries (8). U. necator was halted by ontogenic resistance in many cases before formation of visible penetration pores. Hence, the mechanisms of ontogenic resistance operated at, or very near, the interface between the appressorium and the berry cuticle. The present study, while coincident with the above, focused on anatomical and biochemical features and responses of the host tissue (i.e., berry epidermal cells) and how these change with berry age.

The berry cuticle is the first potential barrier encountered by the pathogen. Cuticle thickness increased with age in Concord and Chardonnay berries, as berries acquired ontogenic resistance during the first 4 weeks after bloom. In contrast, the thickness of epidermal cell walls did not change significantly during the same period. Interestingly, the cuticle of young susceptible Concord berries ( 8 days postbloom) was thicker than the cuticle of older resistant Chardonnay berries (28 days postbloom). Heinz and

A

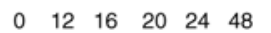

Inoculated

Noninoculated

$\begin{array}{llllll}0 & 12 & 16 & 20 & 24 & 48\end{array}$
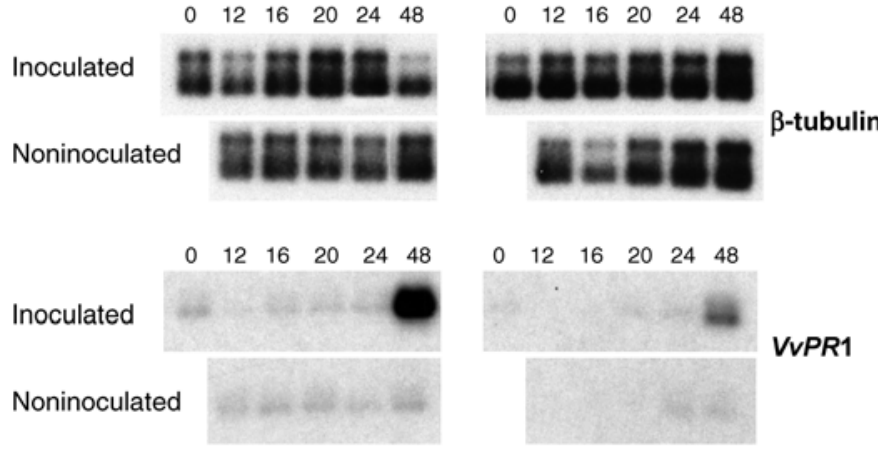

$\begin{array}{llllll}0 & 12 & 16 & 20 & 24 & 48\end{array}$
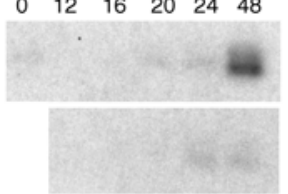

VvPR1

Noninoculated

$\begin{array}{llllll}0 & 12 & 16 & 20 & 24 & 48\end{array}$

Inoculated

Noninoculated

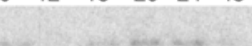

$\begin{array}{llllll}0 & 12 & 16 & 20 & 24 & 48\end{array}$

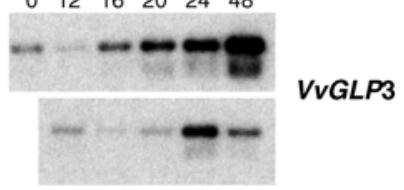

Fig. 6. Reverse transcriptase-polymerase chain reaction/Southern blot analysis of gene expression in skins of Vitis vinifera 'Chardonnay' berries. Berries were inoculated A, 7 and $\mathbf{B}, 39$ days after bloom. Uninoculated berries were sampled at the same times to serve as controls. Blots were hybridized with ${ }^{32} \mathrm{P}$-labeled DNA probes of $\beta$-tubulin, $V \nu \mathrm{PR}-1$, and $V v \mathrm{GLP} 3$ as described in the text.
Blaich (11) reported that differences in cuticle and cell wall thickness of leaf epidermal cells of various grape cultivars were correlated with susceptibility of the cultivars to powdery mildew. Mence and Hildebrant (14) also reported a correlation between cuticular thickness and resistance of rose leaves to powdery mildew (Sphaerotheca pannosa), but noted that the cuticle was not a barrier to penetration. In our study, simple dimensional changes in these preexisting barriers (i.e., the cuticle and epidermal cell wall) were unrelated to observed changes in ontogenic resistance of berries. This does not rule out the occurrence of ultrastructural or biochemical changes, either induced or constitutive, that might make the cuticle or cell wall more resistant to penetration, and this is a focus of our continuing studies.

Autofluorescent phenolics that accumulate at infection sites have been suggested to have antifungal properties or to function as elicitors for wound responses on grape leaves during infection by $U$. necator $(12)$ and in other pathosystems $(2,4)$. Oxidization of polyphenolics that accumulated in epidermal cells subtending appressoria of $U$. necator on grape leaves was associated with epidermal cell death, and consequently the death of haustoria contained in those cells (12). Our results indicate that in the case of grape berries, polyphenolic synthesis and oxidation is a response to wounding during successful infection, that it is therefore primarily restricted to young susceptible tissues and is not a principal cause of ontogenic resistance. Among 24-day-old Chardonnay berries, less than $2 \%$ of conidia bearing appressoria were associated with any detectable autofluorescence (Table 1). Autofluorescence occurred far more frequently $(62 \%)$ beneath appressoria on young berries (Table 1). However, in the case where secondary hyphae were produced on 7-day-old berries, indicating successful pathogen establishment and growth, the frequency of autofluorescence in epidermal cells subtending appressoria was equal $(P=0.01)$ to the frequency of no autofluorescence (Table 1). Therefore, at $48 \mathrm{~h}$ after inoculation, polyphenolic accumulation was nearly absent in resistant berry epidermal tissue, and in susceptible tissue seemed unrelated to successful establishment and growth (Table 1). When berries were examined several days after inoculation, the frequency of cell discoloration on older berries often exceeded the level of autofluorescence observed at $48 \mathrm{~h}$ after inoculation (Figs. 2 and 3), so apparently polyphenolic accumulation and subsequent oxidation does eventually occur on ontogenically resistant berry tissues. However, the levels of discoloration remained higher in the younger susceptible berries than in older ones (Figs. 2 and 3). The time-course studies of discoloration reported in Figures 3 and 4 illustrate how the extent of epidermal cell discoloration was a function of both tissue age and duration of the parasitic association (i.e., age of the appressorium). In tissue susceptible at the time of inoculation, polyphenolic synthesis and oxidation at the site of the first-formed appressorium can be extensive over a period of 7 days (Fig. 4) and might indeed be responsible for the eventual decline in hyphal viability as berries (and colonies) aged, as observed in our parallel studies reported earlier (8). However, all of our previous observations (8) show that pathogen ingress on ontogenically resistant berries is halted within $24 \mathrm{~h}$ after inoculation, prior to penetration of the epidermal cell wall and before polyphenolic synthesis and oxidation is detected in ontogenically resistant berries.

Likewise, among all germinated conidia, papillum formation beneath the first-formed appressoria at $24 \mathrm{~h}$ postinoculation was primarily a response observed on susceptible berries (Fig. 5A, B, and $\mathrm{F}$ ), although in a single instance it was observed at a comparable frequency among 4- and 31-day-old Riesling berries at $72 \mathrm{~h}$ postinoculation (Fig. 5C). Of the few papillae that did form on older berries, 82.8 to $97.3 \%$ were located beneath appressoria of conidia that had failed to produce secondary hyphae (Table 2), whereas the more numerous papillae on susceptible berries were less frequently associated with failure of conidia to produce secondary hyphae (Table 2). Papillum formation was therefore a 
common feature coincident with effective penetration and establishment of the pathogen in susceptible berries, where it did not completely contain the pathogen (Fig. 5). In contrast, the pathogen was stopped prior to penetration of resistant berries (8), and this thwarting of penetration most frequently occurred without subtending papillae (Fig. 5).

In attempt to obtain an insight into the molecular basis of ontogenic resistance, studies were undertaken to determine if any differences in gene expression could be detected between susceptible and ontogenically resistant berries within the first $48 \mathrm{~h}$ after inoculation. Initial research focused on potential differences in PR protein gene expression. Significantly higher induction of PR1 gene expression was observed in skins of 7-day-old susceptible Chardonnay berries within $48 \mathrm{~h}$ of inoculation than was observed in 39-day-old resistant berries which suggests that induction of this PR gene could be a wound response from infected cells rather than an effective defense against $U$. necator. In contrast, expression of the GLP gene $V v$ GLP3 appeared to be upregulated when resistant berries were inoculated, but was absent following inoculation of young susceptible berries. Thus, expression of this $V v$ GLP3 gene appears to correlate with the early cessation of pathogen development on fully resistant berries. The function of this gene in grape berries has not yet been identified. However, studies on barley and wheat powdery mildew (19) suggest that it might be involved in cross-linking reactions associated with the epidermal cell wall, thereby inhibiting penetration. Schweizer et al. (19) found that when expressed as a transgene, GLP became trapped within or close to the vicinity of papillae formed in wheat leaves inoculated with powdery mildew. In ontogenically resistant grape berries, penetration by U. necator is halted before papillum formation, leading us to speculate that in older grape berries the initial site of GLP-mediated cross-linking may be within the cell wall at the site of attempted penetration.

It appears that even susceptible berries may have anatomical and biochemical mechanisms that may be partially effective against $U$. necator, such as accumulation and oxidation of polyphenolics, papillum formation, and induction of PR genes. However, in the susceptible berries these responses do not prevent pathogen ingress and growth sufficiently to prevent establishment of $U$. necator. They may eventually slow the rate of pathogen growth and cause mortality of hyphae in the mildew colony, as has been observed in our parallel studies (8). As the berry matures, ontogenic resistance is almost completely effective in successfully stopping fungal establishment within $24 \mathrm{~h}$ after arrival of the inoculum, but it does so before many of the above named responses are fully expressed. Our results indicate that the cuticle and cell wall of ontogenically resistant berries are impervious to penetration by $U$. necator, but that this is not related to a variety of induced responses or constitutive barriers implicated in host resistance in grapevine leaves and other pathosystems $(2,4,11,12,14,16,17,20)$. Thus far, it seems the most likely mechanism might involve biochemical or ultrastructural modifications of the cuticle or cell wall that prevent penetration of ontogenically resistant berries.

\section{ACKNOWLEDGMENTS}

This thesis was supported by the USDA/FAS/OICD/RSED competitive grants program, by the USDA Viticulture Consortium, the New York Wine and Grape Foundation, the Lake Erie Regional Grape Program, and the Kaplan Fund. The Commonwealth Science and Industry Research Organization hosted A. Ficke as a visiting scholar on four occasions between 1998 and 2001. The research described herein represents a por- tion of a thesis submitted by A. Ficke to the Graduate School of Cornell University in partial fulfillment of requirements for the Ph.D. in plant pathology. We thank M. Goffinet and M. J. Welser of the Department of Horticultural Sciences at NYSAES for assistance with the anatomical studies and technical help and T. King at CSIRO for excellent technical assistance.

\section{LITERATURE CITED}

1. Bioletti, F. T. 1907. Oidium or powdery mildew of the vine. Calif. Agric. Exp. Stn. Bull. 186:315-350.

2. Carver, T. L., Zhang, L., Zeyen, R. J., and Robbins, M. P. 1996. Phenolic biosynthesis inhibitors suppress adult plant resistance to Erysiphe graminis in oat at $20^{\circ} \mathrm{C}$ and $10^{\circ} \mathrm{C}$. Physiol. Mol. Plant Pathol. 49:121141.

3. Chellemi, D. O., and Marois, J. J. 1992. Influence of leaf removal, fungicide applications, and fruit maturity on incidence and severity of grape powdery mildew. Am. J. Enol. Vitic. 43:53-57.

4. Clark, T. A., Zeyen, R. J., Smith, A. G., Carver, T. L., and Vance, C. P. 1994. Phenylalanine ammonia lyase mRNA accumulation, enzyme activity and cytoplasmic responses in barley isolines, differing at MI- $a$ and MI-o loci, attacked by Erysiphe graminis f. sp. hordei. Physiol. Mol. Plant Pathol. 44:171-185.

5. Davies, C., and Robinson, S. 1996. Sugar accumulation in grape berries: Cloning of two vacuolar invertase cDNAs and their expression in grapevine tissues. Plant Physiol. 111:275-283.

6. Delp, C. 1954. Effect of temperature and humidity on the grape powdery mildew fungus. Phytopathology 44:615-626.

7. Derckel, J. P., Legendre, L., Audran, J. C., Haye, B., and Lambert, B. 1996. Chitinases of the grapevine (Vitis vinifera L.): Five isoforms induced in leaves by salicylic acid are constitutively expressed in other tissue. Plant Sci. 119:31-37.

8. Ficke, A., Gadoury, D. M., Seem, R. C., and Dry, I. B. 2003. Effects of ontogenic resistance upon establishment and growth of Uncinula necator on grape berries. Phytopathology 93:556-563.

9. Gadoury, D. M., Seem, R. C., Ficke, A., and Wilcox, W. F. 2001. The epidemiology of powdery mildew on Concord grapes. Phytopathology 91:948-955.

10. Gadoury, D. M., Seem, R. C., Ficke, A., and Wilcox, W. F. 2003. Ontogenic resistance to powdery mildew in grape berries. Phytopathology 93:547-555.

11. Heintz, C., and Blaich, R. 1989. Structural characters of epidermal walls and resistance to powdery mildew of different grapevine cultivars. Vitis 28:153-160.

12. Heintz, C., and Blaich, R. 1990. Ultrastructural and histochemical studies on interactions between Vitis vinifera L. and Uncinula necator (Schw.) Burr. New Phytol. 115:107-117.

13. Johansen, D. A. 1940. Plant Mircotechnique. The Botanical Sciences. E. W. Sinnott, ed. McGraw-Hill, New York.

14. Mence, M. J., and Hildebrandt, A. C. 1966. Resistance to powdery mildew in rose. Ann. Appl. Biol. 58:309-321.

15. Phillips, J. K., and Hayman, D. S. 1970. Improved procedure for clearing roots and staining parasitic and vesicular-arbuscular mycorrhizal fungi for rapid assessment of infection. Trans. Br. Mycol. Soc. 55:158-161.

16. Pratt, C., Goffinet, M. C., Welser, M. J., and Pearson, R. C. 1984. Powdery mildew of Vitis: Papillae (wall appositions) as a host response to infection. Vitis 23:225-229.

17. Robinson, S. P., Jacobs, A. K., and Dry, I. B. 1997. A class IV chitinase is highly expressed in grape berries during ripening. Plant Physiol. 114:771778.

18. Sambrook, J., Fritsch, E. F., and Maniatis, T. 1989. Molecular Cloning. Vol. 2. Cold Spring Harbor Laboratory, Cold Spring Harbor, NY.

19. Schweizer, P., Christoffel, A., and Dudler, R. 1999. Transient expression of members of the germin-like gene family in epidermal cells of wheat confers disease resistance. Plant J. 20:541-552.

20. Tattersall, D. B., van Heeswijck, R., and Hoj, P. B. 1997. Identification and characterization of a fruit-specific, thaumatin-like protein that accumulates at very high levels in conjunction with the onset of sugar accumulation and berry softening in grapes. Plant Physiol. 114:759769.

21. Viala, P. 1893. Les Maladies de la Vigne. Masson \& Cie, Paris. 